\title{
STUDI INTERAKSI MOLEKULAR SENYAWA HESPERIDIN DAN NOBILETIN KULIT BUAH JERUK TERHADAP ENZIM TYROSINASE SECARA IN SILICO
}

\author{
Sani Ega Priani*, Taufik Muhammad Fakih
}

Program Studi Farmasi, Fakultas Matematika dan IImu Pengetahuan Alam, Universitas Islam Bandung

Jl. Rangga Gading No. 8, Bandung 40116, Indonesia

Info Article

Submitted :

30 September 2020

\section{Revised :}

18 November 2020

Accepted :

25 November 2020

\section{Corresponding Author:}

Sani Ega Priani

\section{Email :}

egapriani@gmail.com 
was carried out by in silico study. Macromolecular model of the tyrosinase enzyme was prepared and followed by determining the active site of the enzyme using tyrosine as its natural ligand. Furthermore, the study of molecular interactions between nobiletin and hesperidin on the active site of the tyrosinase enzyme was carried out using the molecular docking method. The results showed that nobiletin and hesperidin had an ability to bind to the active site of the enzyme with free binding energies are -6.24 and $6.73 \mathrm{kcal} / \mathrm{mol}$. The binding energies of the compounds to active site of the enzyme are better compared with the natural ligand (tyrosine), which is $-4.91 \mathrm{kcal} / \mathrm{mol}$. Hesperidin and nobiletin interact with the active site of the enzyme by hydrogen bonding and hydrophobic interactions. Nobiletin is also able to bind with $\mathrm{Cu}$ ion which is on the active site of the enzyme. From these results, it can be concluded that the nobiletin and hesperidin could be act as competitive inhibitors of the tyrosinase enzyme based on in silico study.

Keywords: nobiletin, hesperidin, citrus peel, tyrosinase, in silico

\section{PENDAHULUAN}

Jeruk merupakan salah satu tanaman buah dunia yang paling diminati, mengandung banyak senyawa aktif yang baik untuk kesehatan. Jeruk diketahui mengandung vitamin C, asam folat, kalium dan pektin. Selain itu buah jeruk diketahui mengandung senyawa-senyawa metabolit sekunder seperti polifenol dan flavonoid yang membuatnya memiliki aktivitas antioksidan yang tinggi (Sidana et al, 2013). Produksi jeruk di Indonesia sendiri sangat tinggi, menurut data diketahui pada tahun 2020 produksi jeruk di Indonesia dapat mencapai angka 3 juta ton setahun. Tingginya produksi dan konsumsi buah jeruk tersebut menyebabkan tingginya juga limbah yang dihasilkan, yakni bagian kulit buahnya. Bagian kulit buah jeruk belum dimanfaatkan secara optimal, padahal beberapa penelitian menunjukkan banyaknya senyawa berkhasiat yang terkandung dalam kulit buahnya.

Kulit jeruk kaya akan bahan fungsional seperti minyak esensial (0,6 -
$1 \%)$, serat $(6,30-42,13 \%)$, fenol $(0,67-19,62$ $\%)$, dan vitamin C $(0,109-1,150 \%)$. Senyawa fenolik utama yang terkandung dalam kulit buah jeruk adalah flavanon (hesperidin, neohesperidin, narirutin, dan naringin) dan flavon terpolimetoksilasi (nobiletin, sinensetin, tangeretin). Kandungan senyawa fenolik dari kulit buah jeruk menyebabkan munculnya banyak aktivitas farmakologi seperti antioksidan, anti-inflamasi, anti-kanker, anti-proliferasi, anti-virus, dan anti agregasi platelet (Mhiri et al, 2013; Rafiq et al, 2018, Koolaji et al, 2020).

Kandungan senyawa-senyawa flavonoid yang terkandung dalam kulit jeruk membuatnya potensial dikembangkan menjadi senyawa aktif dalam produk kosmetika. Salah satu aktivitas yang sering dimiliki oleh senyawasenyawa flavonoid adalah aktivitas inhibitor enzim tirosinase (Sohretoglu et al, 2018). Enzim tirosinase adalah suatu enzim yang mengkatalisis proses pembentukan atau sintesis melanin di kulit. Penggunaan senyawa-senyawa yang memiliki 
kemampuan menghambat kerja enzim ini, dapat membantu mengatasi kondisi hiperpigmentasi kulit. Hiperpigmentasi adalah suatu kondisi dimana terjadinya produksi pigmen kulit/melanin yang berlebihan, sehingga dapat menjadi masalah penting terutama untuk kaum wanita. Senyawa flavonoid diketahui dapat menjadi inhibitor kompetitif enzim tyrosinase karena kemampuannya untuk berikatan dengan sisi aktif enzim (Chang, 2009; Sarkar et al, 2013).

Penelitian ini bertujuan untuk mengetahui interaksi molekular antara dua senyawa flavonoid utama yang terkandung dalam kulit buah jeruk yakni hesperidin dan nobiletin dengan sisi aktif enzim tirosinase. Pengujian akan dilakukan secara in silico sehingga dapat ditentukan kekuatan ikatan yang terbentuk dan juga dapat diketahui jenis ikatan yang terjadi serta komponen komponen yang terlibat dalam interaksi tersebut.

\section{METODE PENELITIAN}

\subsection{Preparasi Makromolekul Enzim dan Senyawa Uji}

Struktur kristal makromolekul enzim tyrosinase yang telah diunduh dari web Protein Data Bank dengan kode PDB 6JU9 selanjutnya dipreparasi terlebih dahulu dengan menggunakan perangkat lunak MGLTools 1.5.6 yang dilengkapi dengan AutoDock 4.2. Preparasi makromolekul enzim ini dilakukan dengan menghilangkan molekul air dan ligan alami, kemudian dilanjutkan dengan menambahkan atom hidrogen polar dan menghitung muatan parsial Kollman. Senyawa uji yang akan digunakan dalam penelitian ini adalah hesperidin dan nobiletin. Struktur molekul senyawa diperoleh dari web Pubchem (https://pubchem.ncbi.nlm.nih.gov).
Kemudian, dilakukan preparasi terhadap senyawa uji dengan menambahkan atom hidrogen polar dan menghitung muatan parsial Gasteiger. Preparasi molekul senyawa dilakukan dengan menggunakan perangkat lunak MGLTools 1.5.6 yang dilengkapi dengan AutoDock 4.2. Struktur yang telah dipreparasi selanjutnya akan digunakan sebagai input untuk simulasi penambatan molekuler.

\subsection{Identifikasi Sisi Aktif \\ Makromolekul Enzim}

Makromolekul enzim yang telah dipreparasi kemudian diidentifikasi, dievaluasi, dan dieksplorasi bagian sisi aktif pengikatan yang berperan terhadap aktivitas inhibitor tyrosinase dengan menggunakan perangkat lunak BIOVIA Discovery Studio 2020. Molekul tirosin yang berperan sebagai ligan alami dari makromolekul enzim tirosinase digunakan untuk mengidentifikasi dan mengevaluasi area sisi aktif dari makromolekul enzim tersebut.

\subsection{Simulasi Penambatan Molekuler}

Simulasi penambatan molekuler dilakukan dengan menggunakan perangkat lunak MGLTools 1.5.6 yang dilengkapi dengan AutoDock 4.2 untuk mengamati dan mengidentifikasi afinitas dan interaksi yang terjadi antara makromolekul enzim tirosinase dengan hesperidin dan nobiletin. Jarak antara bagian permukaan makromolekul enzim dan molekul senyawa uji dibatasi dengan batas radius maksimum $0,375 \AA$. Semua simulasi dilakukan menggunakan ukuran grid box $64 \times 60 \times 60$, selanjutnya digunakan metode Lamarckian Genetic Algorithm dengan 100 konformasi. Hasil penambatan molekuler kemudian dilakukan identifikasi dan evaluasi terhadap interaksi molekuler yang terjadi 
antara makromolekul enzim tirosinase dengan molekul senyawa uji berdasarkan nilai energi bebas ikatan. Residu asam amino yang berperan dalam interaksi molekuler yang terbentuk diamati dengan menggunakan perangkat lunak BIOVIA Discovery Studio 2020 (Cenol et al, 2014).

\section{HASIL DAN PEMBAHASAN}

Enzim tirosinase diketahui sebagai suatu enzim yang mengkatalisis proses melanogenesis. Proses melanogenesis adalah suatu proses sintesis melanin atau pigmen kulit. Melanogenesis dimulai dengan tahap oksidasi tirosin menjadi dopaquinone yang dikatalisis langsung oleh enzim tirosinase. Melanin berperan penting dalam melindungi kulit manusia dari efek berbahaya radiasi UV dari matahari. Melanin juga menentukan penampilan fenotipik kita. Pada kondisi kondisi tertentu dapat terjadi proses produksi melanin yang berlebihan yang disebut dengan kondisi hiperpigmentasi. Untuk mengatasi kondisi tersebut umum digunakan senyawa-senyawa yang mampu menghambat kerja enzim tirosinase sehingga menghambat pula sintesis melanin (Chang, 2012). Senyawa senyawa yang mampu berikatan dengan sisi aktif enzim berpotensi untuk dikembangkan sebagai inhibitor enzim tirosinase. Salah satu cara untuk mengetahui keberadaan interaksi antara senyawa uji dengan enzim adalah dengan studi in silico (Asazdeh et al, 2015). Berikut hasil studi yang menggambarkan struktur enzim tyrosinase yang diketahui mampu membentuk kompleks dengan tirosin (Gambar 1).

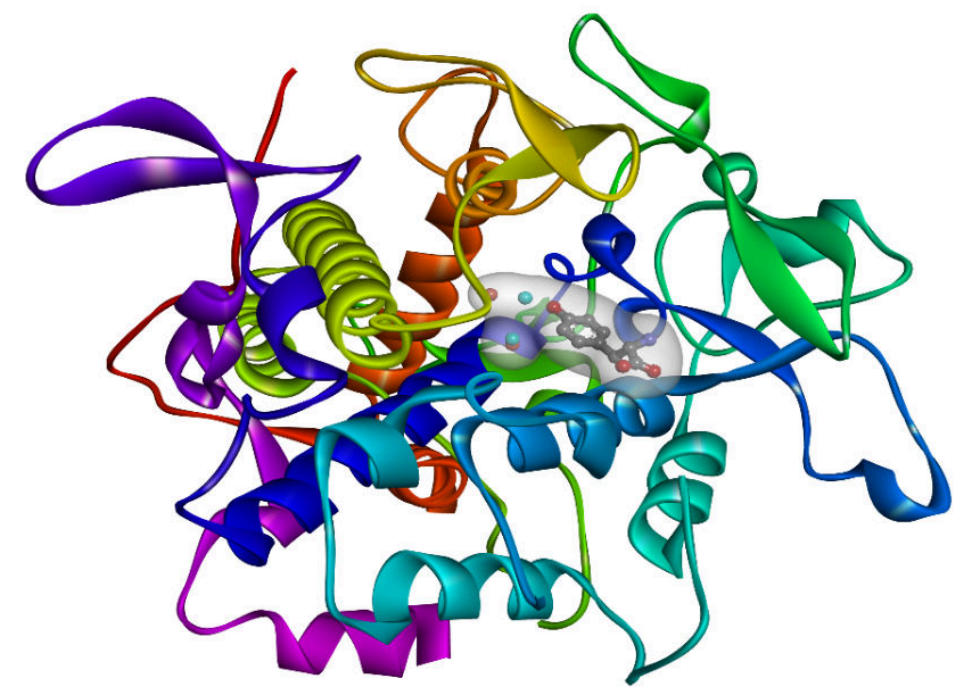

Gambar 1. Struktur makromolekul enzim tyrosinase (dalam kompleks dengan tirosin).

Selanjutnya dilakukan uji untuk mengetahui sisi aktif enzim tirosinase. Untuk dapat menentukan bagian sisi aktifnya, digunakan molekul tirosin yang merupakan substrat atau ligan alami dari enzim tirosinase pada proses melanogenesis. Hasil uji dapat dilihat pada Gambar 2. Dari gambar tersebut dapat terlihat bentuk interaksi yang terjadi antara senyawa aktif dengan tirosin, beserta asam amino serta atom yang terlibat dalam interaksi. 


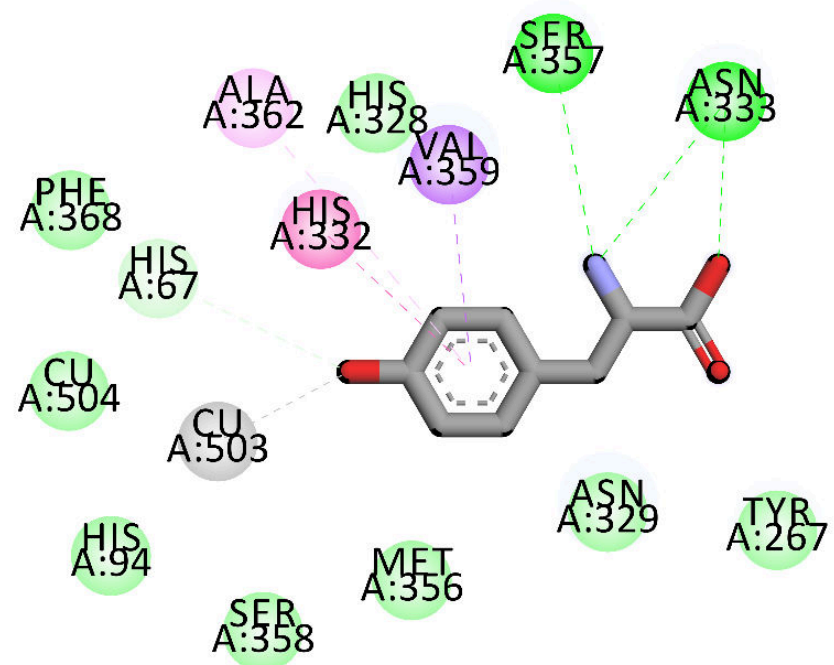

Gambar 2. Hasil analisis sisi aktif enzim tirosinsae yang berikatan dengan tirosin.

Setelah diketahui bagian sisi aktif dari enzim tirosinase tersebut, maka dilanjutkan dengan uji penambatan molekular untuk melihat kemampuan ikatan dari senyawa hesperidin dan nobiletin terhadap bagian sisi aktif tersebut. Hesperidin merupakan flavonoid jenis flavanon dalam bentuk glikosida. Nobiletin masuk golongan flavonoid yang berada dalam bentuk polimetoksiflavon. Hesperidin dan nobiletin ditemukan pada berbagai jenis kulit buah jeruk baik jeruk manis (Citrus sinensis), jeruk keprok (Citrus reticulata), jeruk bali (Citrus maxima), jeruk nipis (Citrus aurantifolia), dll. (Chen et al, 2020; Sharma et al, 2013). Senyawa hesperidin dan nobiletin ini kemudian dilakukan uji in silico untuk mengetahui kemampuan senyawa tersebut untuk berikatan atau berinteraksi dengan sisi aktif enzim tyrosinase. Hasil uji diperlihatkan pada Gambar $\mathbf{3}$ dan Gambar 4. Dari hasil visualisasi dapat diketahui bahwa senyawa hesperidin dan nobiletin mampu berikatan dengan bagian sisi aktif enzim tirosinase pada sisi yang sama dengan tirosin, sebagai ligan alaminya.

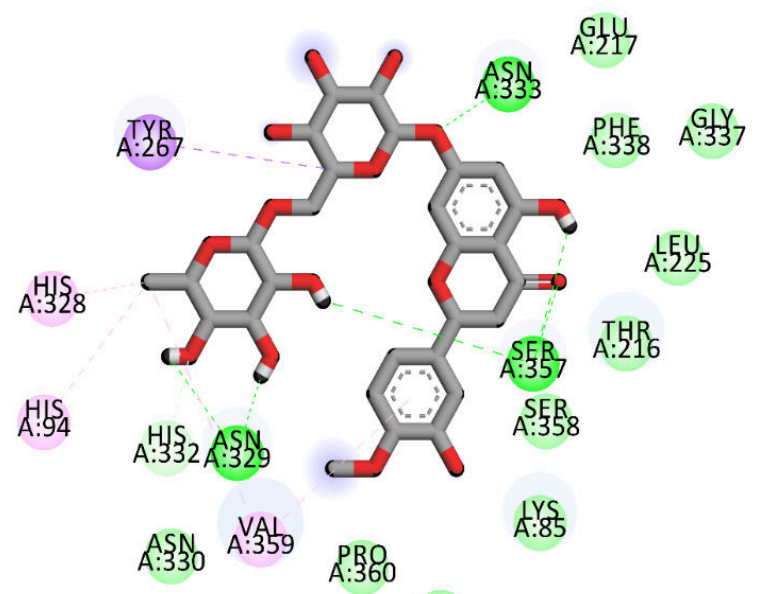

A.:SB A.SN

Gambar 3. Interaksi molekular antara hesperidin dengan sisi aktif enzim tyrosinase. 


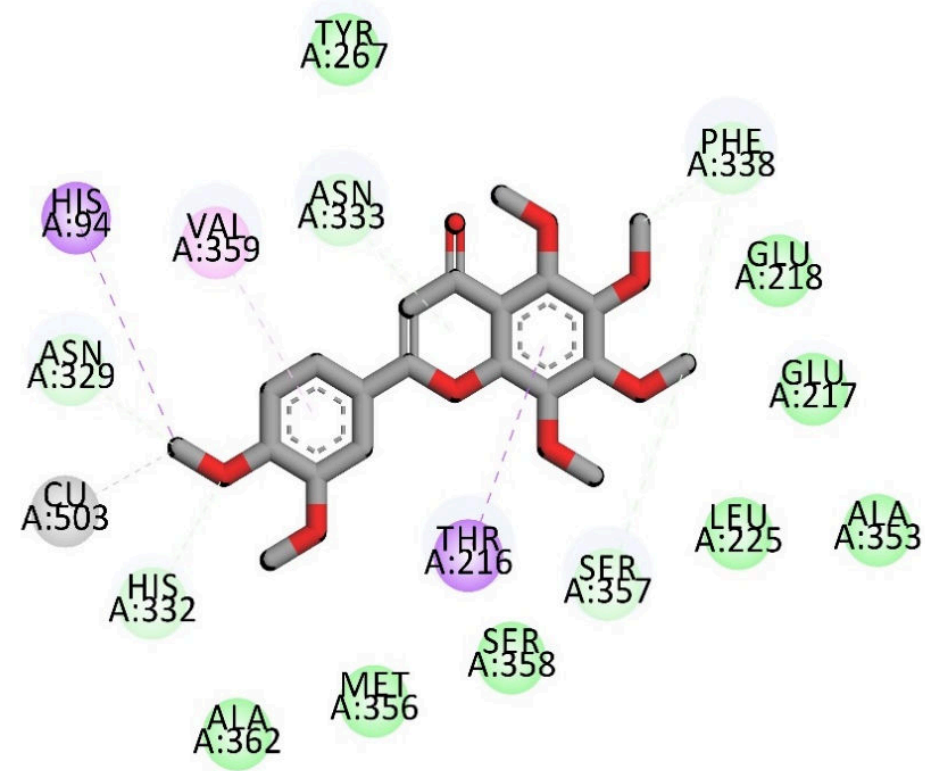

Gambar 4. Interaksi molekular antara nobiletin dengan sisi aktif enzim tyrosinase.

Selanjutnya dilakukan evaluasi mengetahui nilai energi bebas ikatan dan interaksi antara senyawa hesperidin dan juga jenis ikatan yang terjadi. Hasilnya nobiletin dengan sisi aktif enzim ditampilkan pada Tabel 1 dan Tabel 2. tyrosinase. Evaluasi yang dilakukan untuk

Tabel 1. Energi bebas ikatan hasil simulasi penambatan molekuler.

\begin{tabular}{cc}
\hline Nama Senyawa & Nilai Energi Bebas Ikatan (kkal/mol) \\
\hline Tirosin & $-4,91$ \\
Hesperidin & $-6,73$ \\
Nobiletin & $-6,24$ \\
\hline
\end{tabular}

Dari hasil pada Tabel 1 terlihat nilai energi bebas ikatan yang terbentuk antara tirosin sebagai ligan alami dan senyawa uji yakni hesperidin dan nobiletin dengan sisi aktif enzim tirosinase. Dari hasil yang diperoleh diketahui bahwa ikatan atara hesperidin dan nobiletin dengan sisi aktif enzim tirosinase lebih kuat jika dibandingkan dengan tirosin sebagai ligan alami. Hal tersebut disebabkan karena, semakin negatif nilai energi bebas ikatan, semakin kuat ikatan yang terbentuk. Dapat diprediksi bahwa hesperidin dan nobiletin mampu berkompetisi dengan tirosin dalam penempatan sisi aktif sehingga potensial menjadi inhibitor enzim tirosinase. 
Tabel 2. Energi bebas ikatan hasil simulasi penambatan molekuler.

\begin{tabular}{|c|c|c|c|c|}
\hline Nama Senyawa & $\begin{array}{c}\text { Jumlah } \\
\text { Interaksi }\end{array}$ & $\begin{array}{c}\text { Interaksi } \\
\text { hidrofobik }\end{array}$ & Ikatan hidrogen & $\begin{array}{c}\text { Ikatan dengan } \\
\text { Cu }\end{array}$ \\
\hline $\begin{array}{c}\text { Tirosin } \\
\text { (ligan alami) }\end{array}$ & 7 & His332, Val 359 & $\begin{array}{c}\text { His67, Asn333, } \\
\text { Ser357 }\end{array}$ & Ada \\
\hline Hesperidin & 13 & $\begin{array}{l}\text { His94, Tyr267, } \\
\text { His328, Val359 }\end{array}$ & $\begin{array}{l}\text { Asn329, His332, } \\
\text { Asn333, Ser357 }\end{array}$ & Tidak \\
\hline Nobiletin & 10 & His94, Thr216, Val359 & $\begin{array}{c}\text { Asn329, His332, } \\
\text { Asn333, Phe338, } \\
\text { Ser357 }\end{array}$ & Ada \\
\hline
\end{tabular}

Dari hasil pada Tabel 2, ada tiga jenis interaksi yang dapat terjadi yakni interaksi hidrofobik, ikatan hidrogen, dan ikatan dengan $\mathrm{Cu}$. Dilihat dari jumlah interaksinya hesperidin memiliki jumlah interaksi yang paling banyak dibandingkan dengan tirosin dan nobiletin, sehingga memiliki energi bebas ikatan paling negatif. Namun baik tirosin dan nobiletin memiliki ikatan/interaksi selain interaksi hidrofobik dan ikatan hidrogen, yakni ikatan dengan logam $\mathrm{Cu}$. Enzim tirosinase merupakan metaloenzim yang mengandung logam $\mathrm{Cu}$. Beberapa senyawa flavonoid diketahui bisa menjadi copper chelator yang mampu berikatan dengan $\mathrm{Cu}$ pada sisi aktif enzim, yang dapat mendukung kemampuannya untuk menginhibisi enzin tyrosinase. Untuk senyawa hesperidin yang tidak dapat berinteraksi dengan $\mathrm{Cu}$ pada sisi aktif enzim, pada penelitian lanjutan perlu dilakukan modifikasi struktural dengan metode HKSA (hubungan kuantitatif struktur aktivitas) agar dihasilkan senyawa turunan yang memiliki kemampauan sebagai copper chelator (Samaneh et al, 2018).

Dari hasil penelitian diketahui bahwa baik senyawa hesperidin ataupun nobiletin menurut uji secara in silico dapat menjadi inhibitor kompetitif enzim tyrosinase, karena mampu berikatan pada sisi aktif yang sama dengan tirosin. Hal ini membuat limbah kulit buah jeruk yang mengandung senyawa hesperidin dan nobiletin berpotensi digunakan sebagai agen inhibitor tyrosinase yang salah satunya dapat dikembangkan menjadi kosmetika mengatasi kondisi hiperpigmentasi kulit.

\section{KESIMPULAN}

Senyawa hesperidin dan nobiletin mampu berikatan dengan sisi aktif enzim tyrosinase dengan besar energi ikatan berturut turut $-6,73$ dan $-6,24 \mathrm{kkal} / \mathrm{mol}$, lebih negatif dibandingkan energi ikatan tirosin sebagai ligan alami yang artinya menggambarkan ikatan senyawa uji yang lebih kuat. Senyawa hesperidin membentuk ikatan dengan sisi aktf enzim dengan ikatan hidogen dan interaksi hidrofobik sedangkan senyawa nobiletin berikatan dengan ikatan hidrogen, interaksi hidorfobik, dan ikatan dengan logam Cu+.

\section{UCAPAN TERIMA KASIH}

Kami ucapkan terima kasih kepada Prodi Farmasi UNISBA yang membantu sehingga penelitian ini dapat terlaksana.

\section{DAFTAR PUSTAKA}

Asadzadeh A, Fassihi A, Yaghmaei P, Pourfarzam., 2015. In Silico Approach for Designing Potent Inhibitors against Tyrosinase, Biosciences, 12: 181-187.

Chang TS., 2009. An updated review of 
tyrosinase inhibitors. Int $J \mathrm{Mol} S c, 10(6)$ : 2440-75.

Chang TS., 2012. Natural Melanogenesis Inhibitors Acting Through the DownRegulation of Tyrosinase Activity. Materials (Basel), 5(9):1661-85.

Chen Q, Wang D, Tan C, Hu Y, Sundararajan B, Zhou Z., 2010. Profiling of Flavonoid and Antioxidant Activity of Fruit Tissues from 27 Chinese Local Citrus Cultivars. Plants (Basel). 9(2):196.

Huang H, Li L, Shi W, Liu H, Yang J, Yuan X, Wu L., 2016. The Multifunctional Effects of Nobiletin and Its Metabolites In Vivo and In Vitro, Evid Based Complement Alternat Med, 2016; 1-14.

Jaspreetkaur S., Vipin S., Sumitra D., Parminder N., Suman B., 2013. A Review on Citrus "The Boon of Nature", Int. J. Pharm. Sci. Rev. Res, 18(2): 20-27.

Koolaji N, Shammugasamy B, Schindeler A, Dong Q, Dehghani F, Valtchev P., 2020. Citrus Peel Flavonoids as Potential Cancer Prevention Agents. Curr Dev Nutr. 4(5).

M'hiri N., I. Ioannou, M. Ghoul, N. Mihoubi Boudhrioua, 2017. Phytochemical characteristics of citrus peel and effect of conventional and nonconventional processing on phenolic compounds: A review, Food Reviews International, 33(6): 587-619
Rafiq, S., Rajkumari K, Sofi A., Nadia B, Fiza N, Gulzar AN, 2018. Citrus peel as a source of functional ingredient: A review, Journal of the Saudi Society of Agricultural Sciences, 17(4): 351-358.

Samaneh Z, Asieh B, Mahmud THK, Munoz M, Garcia M, Garcia C, Ali AS., 2019. A comprehensive review on tyrosinase inhibitors, Journal of Enzyme Inhibition and Medicinal Chemistry, 34(1): 279-309.

Sarkar R, Arora P, Garg KV., 2013. Cosmeceuticals for Hyperpigmentation: What is Available, J Cutan Aesthet Surg, 6(1):4-11.

Senol FS, Khan MT, Orhan G, Gurkas E, Orhan IE, Oztekin NS, Ak F., 2014. In silico approach to inhibition of tyrosinase by ascorbic acid using molecular docking simulations. Curr Top Med Chem. 14(12):1469-72.

Sharma P, Pandey P, Gupta R, Roshan S, Garg A, Shukla A, Pasi A, 2013. Isolation and characterization of hesperidin from orange peel. Indo American Journal of Pharmaceutical Research, 2013:38923897.

Sohretoglu D., Burak B., Arzu O., 2018. Tyrosinase inhibition by some flavonoids: Inhibitory activity, mechanism by in vitro and in silico studies, Bioorganic Chemistry, 81(1): 168-174 